\title{
Haloferax elongans sp. nov. and Haloferax mucosum sp. nov., isolated from microbial mats from Hamelin Pool, Shark Bay, Australia
}

Correspondence

Brett A. Neilan

b.neilan@unsw.edu.au

\author{
Michelle A. Allen, ${ }^{1}$ Falicia Goh, ${ }^{1}$ Stefan Leuko, ${ }^{2}$ Akinobu Echigo, ${ }^{3}$ \\ Toru Mizuki, ${ }^{3}$ Ron Usami, ${ }^{3}$ Masahiro Kamekura, ${ }^{4}$ Brett A. Neilan ${ }^{1,2}$ \\ and Brendan P. Burns ${ }^{1,2}$
}
${ }^{1}$ School of Biotechnology and Biomolecular Sciences, University of New South Wales, Sydney, NSW 2052, Australia
${ }^{2}$ Australian Center for Astrobiology, Macquarie University, Building E8C 153, Sydney, NSW 2109, Australia
${ }^{3}$ Department of Applied Chemistry, Faculty of Engineering, and Bio-Nano Electronics Research Center, Toyo University, 2100 Kujirai, Kawagoe, Saitama 350-8585, Japan
${ }^{4}$ Halophiles Research Institute, 677-1 Shimizu, Noda, Chiba 278-0043, Japan

Hamelin Pool, Shark Bay, Australia, is a hypersaline embayment in which the mean salt concentration is roughly double that of seawater $\left(0.852 \mathrm{M} \mathrm{Na}^{+}, 0.090 \mathrm{M} \mathrm{Mg}^{2+}\right.$, $0.018 \mathrm{M} \mathrm{Ca}^{2+}, 1.01 \mathrm{M} \mathrm{Cl}^{-}$; Arp et al., 2001), with morphologically diverse microbial mats and stromatolites

Abbreviations: DGA-1, diglycosyl archaeol-1; PG, phosphatidylglycerol; PGP-Me, phosphatidylglycerophosphate methyl ester; PGS, phosphatidylglycerosulfate; S-DGA-1, sulfated diglycosyl archaeol-1.

The GenBank/EMBL/DDBJ accession numbers for the $16 \mathrm{~S}$ rRNA gene sequences of Haloferax elongans sp. nov. SA $5^{\top}$ and Haloferax mucosum sp. nov. PA $12^{\top}$ are D0860977 and D0860980, respectively.

Phase-contrast micrographs of late-exponential-phase cells of $\mathrm{SA} 5^{\top}$ and PA $12^{\top}$ (Fig. S1), SDS-PAGE patterns of whole-cell proteins (Fig. S2) and TLC analysis of polar lipids (Fig. S3) of SA5 ${ }^{\top}$ and PA12 ${ }^{\top}$ and reference taxa are available with the online version of this paper. (lithified mats) forming in the intertidal regions. These microbial communities are exposed to salt, desiccation and UV stress, suggesting that they may be habitats for novel biodiversity, and are important for our understanding of stromatolite formation processes. During our surveys of the microbial diversity of the microbial mats and stromatolites of Hamelin Pool (Burns et al., 2004; Allen, 2006; Leuko et al., 2007), 13 archaeal strains were isolated from the smooth and pustular mats of the pool. The smooth mat has an even, light brown/green-pigmented surface and displays defined laminations corresponding to distinct green (cyanobacterial), pink (unknown) and black (sulfate-reducing) layers, whereas the pustular mat has an irregular, dark purple/ brown-pigmented surface comprised predominantly of cyanobacteria and with little observable lamination (Logan et al., 1974; Allen, 2006). The isolates formed two clusters 
(or groups) within the genus Haloferax on the basis of cell morphology and $16 \mathrm{~S}$ rRNA gene sequence analysis.

Currently, there are nine recognized species of Haloferax: Haloferax volcanii (Mullakhanbhai \& Larsen, 1975), Haloferax mediterranei (Rodriguez-Valera et al., 1983), Haloferax denitrificans (Tomlinson et al., 1986), Haloferax gibbonsii (Juez et al., 1986), Haloferax alexandrinus (Asker \& Ohta, 2002), Haloferax lucentense (Gutierrez et al., 2002), Haloferax sulfurifontis (Elshahed et al., 2004), Haloferax prahovense (Enache et al., 2007) and Haloferax larsenii (Xu et al., 2007). In this paper, taxonomic characterization of a representative isolate from each of the clusters described above is presented and two novel species are proposed.

A halophilic archaeal medium [containing $\left(\mathrm{g}^{-1}\right)$ : Casamino acids, 7.5; yeast extract, 10.0; trisodium citrate, $3.00 ; \mathrm{NaCl}$, 150; KCl, 2.00; $\mathrm{MgSO}_{4} .7 \mathrm{H}_{2} \mathrm{O}, 20.0 ; \mathrm{MgCl}_{2} .6 \mathrm{H}_{2} \mathrm{O}, 7.23$; $\mathrm{CaCl}_{2} \cdot 2 \mathrm{H}_{2} \mathrm{O}, 2.70 ; \mathrm{FeSO}_{4} \cdot 7 \mathrm{H}_{2} \mathrm{O}, 0.05 ; \mathrm{MnSO}_{4} \cdot \mathrm{H}_{2} \mathrm{O}$, 0.0002; adjusted to $\mathrm{pH}$ 7.4; Goh et al., 2006] was inoculated with portions of smooth or pustular mat collected from Hamelin Pool in April 2004. Plates were incubated aerobically at $37^{\circ} \mathrm{C}$ in the dark and colonies with pink or red morphology appeared after 2 weeks. The strains were purified by repeated streaking for single colonies and purity was confirmed by uniform cell and colony morphology and by $16 \mathrm{~S}$ rRNA gene amplification and sequencing. DNA extraction and 16S rRNA gene amplification methods have been described previously (Allen, 2006).

On the basis of 16S rRNA gene sequences and colony and cell morphologies, the 13 isolates formed two groups. Seven strains from the smooth mat, designated strains SA1-SA7, and one strain from the pustular mat, designated strain PA15, formed small $(1 \mathrm{~mm})$, red, translucent, convex colonies on agar medium. This group of strains all formed pleomorphic rods (see supplementary Fig. S1 available with the online version of this paper) and analysis of their partial 16S rRNA gene sequences indicated they were most closely related to $H f x$. larsenii $(99.0-99.4 \%$ similarity). Strain $\mathrm{SA}^{\mathrm{T}}$ was selected as a representative strain for further taxonomic characterization.

Five strains, designated PA12-14, PA16 and PA17, isolated from the pustular mat formed pink-red, entire, opaque, domed, mucoid colonies, $3-5 \mathrm{~mm}$ in diameter and exhibited pleomorphic cell morphology (see supplementary Fig. S1 available with the online version of this paper). Analysis of their partial 16S rRNA gene sequences indicated they were most closely related to Hfx. mediterranei (98.1$98.8 \%$ similarity). Strain $\mathrm{PA}^{2} 2^{\mathrm{T}}$ was selected as a representative strain for further taxonomic characterization.

Characterization of strains $\mathrm{SA} 5^{\mathrm{T}}$ and $\mathrm{PA} 12^{\mathrm{T}}$ was carried out according to the proposed minimal standards for the description of novel taxa in the order Halobacteriales (Oren et al., 1997). Morphology, nutritional requirements, growth characteristics, miscellaneous biochemical activities and sensitivity to antimicrobial agents were determined as outlined previously (Goh et al., 2006; Allen, 2006). Hfx. volcanii, $H f x$. mediterranei and $H f x$. lucentense were used as controls for the biochemical tests. Generation times for $\mathrm{SA} 5^{\mathrm{T}}$ and $\mathrm{PA} 12^{\mathrm{T}}$ were determined by the method of Robinson et al. (2005) at 53 and $48{ }^{\circ} \mathrm{C}$, respectively. The $\mathrm{NaCl}, \mathrm{pH}$ and temperature ranges for growth, sensitivity to antibiotics and carbon source utilization results are presented in the species descriptions. Selected characteristics that distinguish strains $\mathrm{SA} 5^{\mathrm{T}}$ and $\mathrm{PA} 12^{\mathrm{T}}$ from other Haloferax species are shown in Table 1.

Of note, strain PA12 ${ }^{\mathrm{T}}$ was oxidase-negative and strain $\mathrm{SA} 5^{\mathrm{T}}$ exhibited an oxidase-variable response (Table 1). The first oxidase-negative halophilic archaeon to be identified (Halococcus hamelinensis) was isolated recently from Hamelin Pool stromatolites (Goh et al., 2006). This suggests that the oxidase-negative phenotype may be a selective advantage in the Hamelin Pool environment. Furthermore, both strains required higher salt levels for growth than are found in Hamelin Pool seawater. Survival and growth of these strains within the Hamelin Pool environment may be facilitated by the intertidal location of the smooth and pustular mats, as regular cycles of desiccation may result in concentrated salt pockets within the fabric of the microbial mats.

Whole-cell protein profiles were determined by SDS-PAGE (Stan-Lotter et al., 2002). SDS-PAGE of whole-cell proteins can be used as a rapid method for distinguishing between bacterial species (Jackman, 1987) and both strains showed different patterns compared to known representatives of the same genus (see supplementary Fig. S2 available with the online version of this paper).

Polar lipids were extracted from SA $5^{\mathrm{T}}, \mathrm{PA} 12^{\mathrm{T}}$ and reference strains by the method of Kamekura (1993). TLC and staining of the lipids was performed as outlined previously (Usami et al., 2005). Both strains possessed sulfated diglycosyl archaeol-1 (S-DGA-1) and lacked phosphatidylglycerosulfate (PGS) (see supplementary Fig. S3 available with the online version of this paper), as is characteristic for species of the genus Haloferax (Kamekura et al., 2004).

Phylogenetic trees were reconstructed from 16S rRNA gene sequences by the neighbour-joining method and the maximum-likelihood algorithm using ARB (Ludwig et al., 2004). Both the neighbour-joining tree (Fig. 1) and the maximum-likelihood tree (not shown) indicated that strain SA5 ${ }^{\mathrm{T}}$ clustered most closely with $H f x$. larsenii and strain $\mathrm{PA} 12^{\mathrm{T}}$ clustered most closely with $H f x$. mediterranei. All signature bases of the genus Haloferax (Kamekura et al., 2004) were conserved in the $16 \mathrm{~S}$ rRNA genes of $\mathrm{SA}^{\mathrm{T}}$ and $\mathrm{PA} 12^{\mathrm{T}}$ and sequence similarities with Halogeometricum borinquense, their closest relative outside the genus Haloferax, were 91.8 and $92.9 \%$, respectively.

DNA G $+\mathrm{C}$ content was determined by the HPLC method of Tamaoka \& Komagata (1984) and DNA-DNA hybridization was performed by the fluorometric method of Ezaki et al. (1989). The two isolates had low DNA-DNA relatedness to each other and to all recognized Haloferax 
Table 1. Phenotypic and other characteristics that distinguish the Hamelin Pool isolates $S A 5^{\top}$ and $P A 12^{\top}$ from other $H a l o f e r a x$ species

Taxa: $1, \mathrm{SA}^{\mathrm{T}}$ (data from this study); 2, $\mathrm{PA}_{2}{ }^{\mathrm{T}}$ (data from this study); 3, Hfx. mediterranei JCM $8866^{\mathrm{T}}$ (Rodriguez-Valera et al., 1983); 4 , Hfx. volcanii JCM $8879^{\mathrm{T}}$ (Mullakhanbhai \& Larsen, 1975); 5, Hfx. lucentense JCM 9276 ${ }^{\mathrm{T}}$ (Gutierrez et al., 2002); 6, Hfx. denitrificans JCM 8864 ${ }^{\mathrm{T}}$ (Tomlinson et al., 1986); 7, Hfx. gibbonsii JCM 8863 ${ }^{\mathrm{T}}$ (Juez et al., 1986); 8, Hfx. alexandrinus JCM 10717 ${ }^{\mathrm{T}}$ (Asker \& Ohta, 2002); 9, Hfx. sulfurifontis JCM $12327^{\mathrm{T}}$ (Elshahed et al., 2004); 10, Hfx. prahovense JCM 13924 ${ }^{\mathrm{T}}$ (Enache et al., 2007); 11, Hfx. larsenii JCM 13917 ${ }^{\mathrm{T}}$ (Xu et al., 2007). Additional data are from Tindall (1992), Tindall et al. (1989), Ventosa (2001) and Robinson et al. (2005). +, Positive; -, negative; \pm , variable; ND, not determined; w, weakly positive.

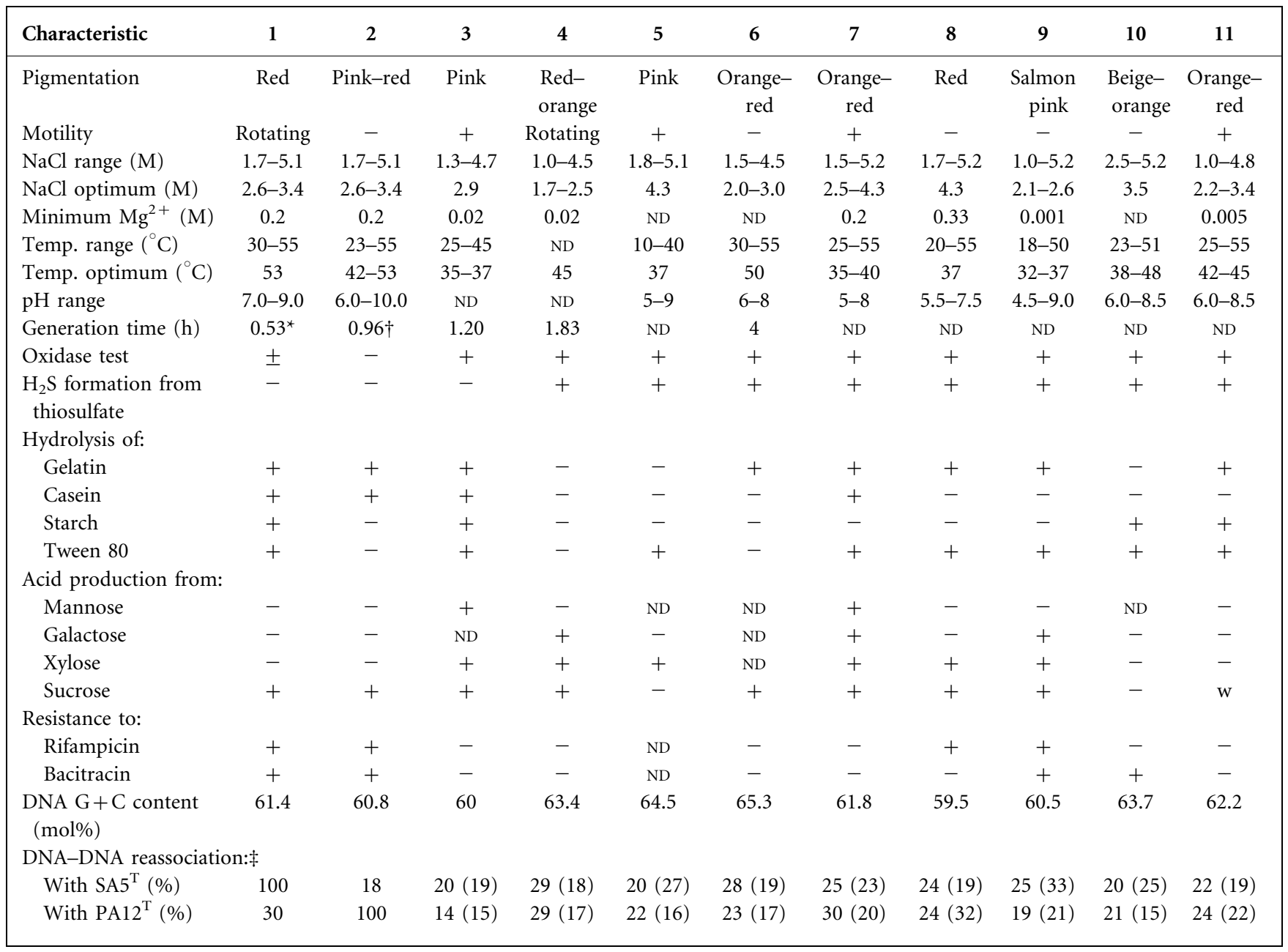

${ }^{\star}$ The generation time for strain $\mathrm{SA} 5^{\mathrm{T}}$ was determined at $53{ }^{\circ} \mathrm{C}$.

$\dagger$ The generation time for strain $\mathrm{PA} 12^{\mathrm{T}}$ was determined at $48^{\circ} \mathrm{C}$.

‡DNA-DNA reassociation values were obtained between non-labelled DNA of reference strains (3-11) and labelled DNA of SA5 ${ }^{\mathrm{T}}$ and PA12 ${ }^{\mathrm{T}}$, respectively. The values in parentheses were obtained between labelled DNA of reference strains and non-labelled DNA of SA5 ${ }^{\mathrm{T}}$ and PA12 ${ }^{\mathrm{T}}$, respectively.

species (33\% or less; Table 1 ), suggesting that strains SA5 ${ }^{\mathrm{T}}$ and $\mathrm{PA} 12^{\mathrm{T}}$ both represent novel species.

Phylogenetic, phenotypic and chemotaxonomic data indicate that strains $\mathrm{SA} 5^{\mathrm{T}}$ and $\mathrm{PA} 12^{\mathrm{T}}$ are members of the genus Haloferax. The DNA-DNA hybridization data, whole-cell protein profiles and phenotypic characteristics (Table 1) justify the creation of two novel species within the genus Haloferax to accommodate these strains, for which the names Haloferax elongans sp. nov. and Haloferax mucosum sp. nov., respectively, are proposed.

\section{Description of Haloferax elongans sp. nov.}

Haloferax elongans (e.lon'gans. N.L. part. adj. elongans elongating/extending, referring to the capacity of the species to form very long rods).

Cells are pleomorphic, with irregular short rods and pleomorphic forms common during stationary phase and in suboptimal media. During exponential growth under optimum conditions, cells elongate to up to $12 \mu \mathrm{m}$ long. Rotational motility is observed in elongated cells. 


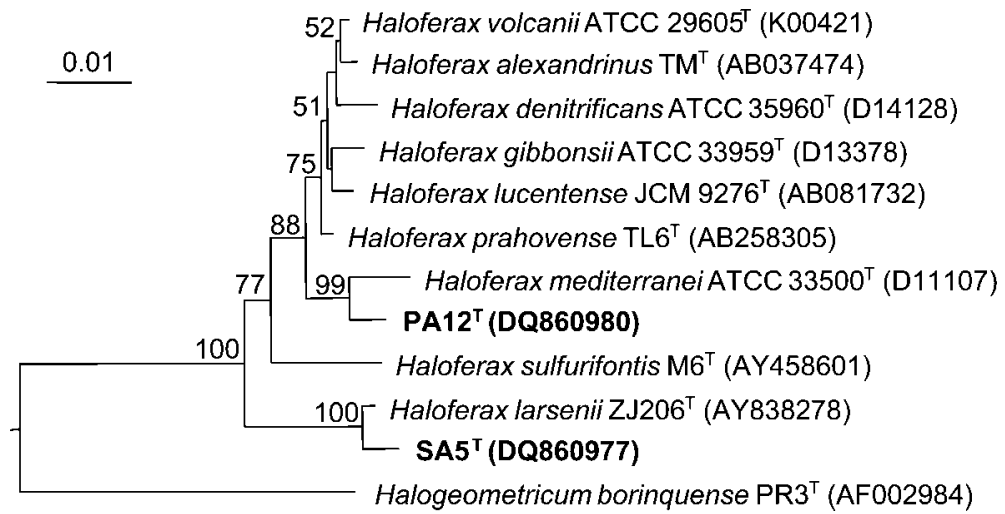

\begin{abstract}
Fig. 1. Neighbour-joining phylogenetic tree, based on 16S rRNA gene sequences, showing the relationships between strains $S A 5^{\top}$ and PA12 ${ }^{\top}$ and related taxa. Bootstrap values $>50 \%$ (1000 resamplings) are shown. Bar, 0.01 substitutions per nucleotide position. Halobacterium salinarum DSM 671 was used as the outgroup (not shown). GenBank accession numbers are indicated for each strain.
\end{abstract}

Gram-negative. Colonies on complex agar medium are small (1-2 mm diameter), red, entire, translucent and convex. Growth occurs in 1.7-5.1 M NaCl, with optimum growth at 2.6-3.4 M NaCl. Growth occurs in media containing at least $0.2 \mathrm{M} \mathrm{Mg}^{2+}$ or more, with an optimum of $0.4 \mathrm{M}$. At least $0.04 \mathrm{M} \mathrm{Mg}^{2+}$ is required for maintenance of native cell morphology and cell lysis occurs in $\mathrm{NaCl}$ solutions of less than $0.85 \mathrm{M}$. Grows at $\mathrm{pH} \mathrm{7.0-9.0} \mathrm{and} \mathrm{30-}$ $55{ }^{\circ} \mathrm{C}$, with optimum growth at $\mathrm{pH} 7.4$ and $53{ }^{\circ} \mathrm{C}$. The generation time at $53{ }^{\circ} \mathrm{C}$ is $32 \pm 3 \mathrm{~min}$. Chemo-organotrophic. Aerobic. Oxidase-variable and catalase-positive. Nitrate is not reduced to nitrite. Does not produce gas from nitrate. Indole is produced from tryptophan. $\mathrm{H}_{2} \mathrm{~S}$ is not produced from thiosulfate. Anaerobic growth is not observed with either nitrate, DMSO or arginine. Gelatin, casein, starch and Tween 80 are hydrolysed. The following substrates are used as carbon sources: glucose, glycerol, maltose, sucrose and trehalose. Acid is produced from glucose, glycerol, maltose, sucrose and trehalose. The following substrates are not used as carbon sources: ethanol, fumarate, galactose, glycine, lactose, mannitol, mannose, raffinose, xylose, L-arginine, L-histidine, L-lysine, L-ornithine and D-sorbitol. Sensitive to novobiocin $\left(50 \mu \mathrm{g} \mathrm{ml}^{-1}\right)$. Resistant to ampicillin, bacitracin, chloramphenicol, cycloheximide, erythromycin, gentamicin, neomycin, penicillin, streptomycin and tetracycline (all at $50 \mu \mathrm{g} \mathrm{ml}^{-1}$ ), ciprofloxacin $(2.5 \mu \mathrm{g}$ per disk), norfloxacin $(10 \mu \mathrm{g}$ per disk) and rifampicin ( $1 \mu \mathrm{g}$ per disk). Lipids S-DGA-1, diglycosyl archaeol-1 (DGA-1), phosphatidylglycerophosphate methyl ester (PGP-Me) and phosphatidylglycerol (PG) are present, but PGS is not present.

The type strain is $\mathrm{SA} 5^{\mathrm{T}}\left(=\mathrm{JCM} 14791^{\mathrm{T}}=\mathrm{ATCC}\right.$ BAA$1513^{\mathrm{T}}=$ UNSW $104100^{\mathrm{T}}$ ), isolated from a smooth mat, Hamelin Pool, Shark Bay, Western Australia. The DNA $\mathrm{G}+\mathrm{C}$ content of the type strain is $61.4 \mathrm{~mol} \%$.

\section{Description of Haloferax mucosum sp. nov.}

Haloferax mucosum (mu.co'sum. L. neut. adj. mucosum slimy, a property of the colonies).

Cells are pleomorphic and non-motile. Gram-negative. Colonies on complex agar medium are $3-5 \mathrm{~mm}$ in diameter, pink-red, entire, opaque, mucoid and domed. Growth occurs in 1.7-5.1 M NaCl, with optimum growth at 2.6-3.4 M. Growth occurs in media containing at least $0.2 \mathrm{M} \mathrm{Mg}^{2+}$ or more. Greater than $0.04 \mathrm{M} \mathrm{Mg}^{2+}$ is required for maintenance of native cell morphology and cell lysis occurs in $\mathrm{NaCl}$ solutions of $0.85 \mathrm{M}$ or less. Grows at $\mathrm{pH}$ 6.0-10.0 and $23-55^{\circ} \mathrm{C}$, with optimum growth at $\mathrm{pH} 7.4$ and $42-53{ }^{\circ} \mathrm{C}$. The generation time at $48{ }^{\circ} \mathrm{C}$ is $57 \pm 3$ min. Chemo-organotrophic. Aerobic. Oxidasenegative and catalase-positive. Nitrate is not reduced to nitrite. Does not produce gas from nitrate. Indole is produced from tryptophan. $\mathrm{H}_{2} \mathrm{~S}$ is not produced from thiosulfate. Anaerobic growth with nitrate, DMSO or arginine does not occur. Gelatin and casein are hydrolysed, but starch and Tween 80 are not. The following substrates are used as carbon sources: glucose, glycerol, maltose, sucrose and trehalose. Acid is produced from glucose, glycerol, maltose, sucrose and trehalose. The following substrates are not used as carbon sources: ethanol, fumarate, galactose, glycine, lactose, mannitol, mannose, raffinose, xylose, L-arginine, L-histidine, L-lysine, L-ornithine and Dsorbitol. Sensitive to novobiocin $\left(50 \mu \mathrm{g} \mathrm{ml}^{-1}\right)$. Resistant to ampicillin, bacitracin, chloramphenicol, cycloheximide, erythromycin, gentamicin, neomycin, penicillin, streptomycin and tetracycline (all at $50 \mu \mathrm{g} \mathrm{ml}^{-1}$ ), ciprofloxacin (2.5 $\mu \mathrm{g}$ per disk), norfloxacin $(10 \mu \mathrm{g}$ per disk) and rifampicin (1 $\mu$ g per disk). Lipids S-DGA-1, DGA-1, PGP-Me and PG are present, but PGS is not present.

The type strain is $\mathrm{PA} 12^{\mathrm{T}}\left(=\mathrm{JCM} 14792^{\mathrm{T}}=\right.$ ATCC BAA$1512^{\mathrm{T}}=$ UNSW $104200^{\mathrm{T}}$ ), isolated from a pustular mat, Hamelin Pool, Shark Bay, Western Australia. The DNA $\mathrm{G}+\mathrm{C}$ content of the type strain is $60.8 \mathrm{~mol} \%$.

\section{Acknowledgements}

We thank the Western Australia Department of Conservation and Land Management for granting permits to sample at World Heritage listed Shark Bay, Mike Dyall-Smith for provision of reference strains, and Hans Trüper for assistance with nomenclature. This work was supported by the Australian Research Council and the Kanagawa Foundation. M. A. A. was supported by an Australian Postgraduate Award, F. G. by the Aus-Asia Award and S. L by an International Postgraduate Research Scholarship. 


\section{References}

Allen, M. A. (2006). An astrobiology-focused analysis of microbial mat communities from Hamelin Pool, Shark Bay, Western Australia. PhD thesis, University of New South Wales, Australia (http://www.library. unsw.edu.au/ thesis/adt-NUN/public/adt-NUN20070215.101356/index. html).

Arp, G., Reimer, A. \& Reitner, J. (2001). Photosynthesis-induced biofilm calcification and calcium concentrations in phanerozoic oceans. Science 292, 1701-1704.

Asker, D. \& Ohta, Y. (2002). Haloferax alexandrinus sp. nov., an extremely halophilic canthaxanthin-producing archaeon from a solar saltern in Alexandria (Egypt). Int J Syst Evol Microbiol 52, 729-738.

Burns, B. P., Goh, F., Allen, M. \& Neilan, B. A. (2004). Microbial diversity of extant stromatolites in the hypersaline marine environment of Shark Bay, Australia. Environ Microbiol 6, 1096-1101.

Elshahed, M. S., Savage, K. N., Oren, A., Gutierrez, M. C., Ventosa, A. \& Krumholz, L. R. (2004). Haloferax sulfurifontis sp. nov., a halophilic archaeon isolated from a sulfide- and sulfur-rich spring. Int J Syst Evol Microbiol 54, 2275-2279.

Enache, M., Itoh, T., Kamekura, M., Teodosiu, G. \& Dumitru, L. (2007). Haloferax prahovense sp. nov., an extremely halophilic archaeon isolated from a Romanian salt lake. Int J Syst Evol Microbiol 57, 393-397.

Ezaki, T., Hashimoto, Y. \& Yabuuchi, E. (1989). Fluorometric deoxyribonucleic acid-deoxyribonucleic acid hybridization in microdilution wells as an alternative to membrane filter hybridization in which radioisotopes are used to determine genetic relatedness among bacterial strains. Int J Syst Bacteriol 39, 224-229.

Goh, F., Leuko, S., Allen, M. A., Bowman, J. P., Kamekura, M., Neilan, B. A. \& Burns, B. P. (2006). Halococcus hamelinensis sp. nov., a novel halophilic archaeon isolated from stromatolites in Shark Bay, Australia. Int J Syst Evol Microbiol 56, 1323-1329.

Gutierrez, M. C., Kamekura, M., Holmes, M. L., Dyall-Smith, M. L. \& Ventosa, A. (2002). Taxonomic description of Haloferax sp. (" $H$. alicantei") strain Aa 2.2: description of Haloferax lucentensis sp. nov. Extremophiles 6, 479-483.

Jackman, P. J. H. (1987). Microbial systematics based on electrophoretic whole-cell protein patterns. Methods Microbiol 19, 209-225.

Juez, G., Rodriguez-Valera, F., Ventosa, A. \& Kushner, D. J. (1986). Haloarcula hispanica spec. nov. and Haloferax gibbonsii spec. nov., two new species of extremely halophilic archaebacteria. Syst Appl Microbiol 8, 75-79.

Kamekura, M. (1993). Lipids of extreme halophiles. In The Biology of Halophilic Bacteria, pp. 135-161. Edited by R. H. Vreeland \& L. I. Hochstein. Boca Raton, FL: CRC Press.

Kamekura, M., Mizuki, T., Usami, R., Yoshida, Y., Horikoshi, K. \& Vreeland, R. H. (2004). The potential use of signature bases from $16 \mathrm{~S}$ rRNA gene sequences to aid the assignment of microbial strains to genera of halobacteria. In Halophilic Microorganisms, pp. 77-100. Edited by A. Ventosa. Berlin: Springer.
Leuko, S., Goh, F., Allen, M. A., Burns, B. P., Walter, M. R. \& Neilan, B. A. (2007). Analysis of intergenic spacer region length polymorphisms to investigate the halophilic archaeal diversity of stromatolites and microbial mats. Extremophiles 11, 203-210.

Logan, B. W., Hoffman, P. \& Gebelein, C. D. (1974). Algal mats, cryptalgal fabrics, and structures, Hamelin Pool, Western Australia. Am Assoc Petroleum Geol Mem 22, 140-194.

Ludwig, W., Strunk, O., Westram, R., Richter, L., Meier, H., Yadhukumar, Buchner, A., Lai, T., Steppi, S. \& other authors (2004). ARB: a software environment for sequence data. Nucleic Acids Res 32, 1363-1371.

Mullakhanbhai, M. F. \& Larsen, H. (1975). Halobacterium volcanii spec. nov., a Dead Sea halobacterium with a moderate salt requirement. Arch Microbiol 104, 207-214.

Oren, A., Ventosa, A. \& Grant, W. D. (1997). Proposed minimal standards for description of new taxa in the order Halobacteriales. Int J Syst Bacteriol 47, 233-238.

Robinson, J. L., Pyzyna, B., Atrasz, R. G., Henderson, C. A., Morrill, K. L., Burd, A. M., DeSoucy, E., Fogleman, R. E., III, Naylor, J. B. \& other authors (2005). Growth kinetics of extremely halophilic Archaea (family Halobacteriaceae) as revealed by Arrhenius plots. $J$ Bacteriol 187, 923-929.

Rodriguez-Valera, F., Juez, G. \& Kushner, D. J. (1983). Halobacterium mediterranei spec. nov., a new carbohydrate-utilizing extreme halophile. Syst Appl Microbiol 4, 369-381.

Stan-Lotter, H., Pfaffenhuemer, M., Legat, A., Busse, H. J., Radax, C. \& Gruber, C. (2002). Halococcus dombrowskii sp. nov., an archaeal isolate from a Permian alpine salt deposit. Int J Syst Evol Microbiol 52, 1807-1814.

Tamaoka, J. \& Komagata, K. (1984). Determination of DNA base composition by reversed-phase high-performance liquid chromatography. FEMS Microbiol Lett 25, 125-128.

Tindall, B. J. (1992). The family Halobacteriaceae. In The Prokaryotes, 2nd edn, vol. 1, pp. 768-808. Edited by A. Balows, H. G. Trüper, M. Dworkin, W. Harder \& K.-H. Schleifer. New York: Springer-Verlag.

Tindall, B. J., Tomlinson, G. A. \& Hochstein, L. I. (1989). Transfer of Halobacterium denitrificans (Tomlinson, Jahnke, and Hochstein) to the genus Haloferax as Haloferax denitrificans comb. nov. Int J Syst Bacteriol 39, 359-360.

Tomlinson, G. A., Jahnke, L. L. \& Hochstein, L. I. (1986). Halobacterium denitrificans sp. nov., an extremely halophilic denitrifying bacterium. Int J Syst Bacteriol 36, 66-70.

Usami, R., Fukushima, T., Mizuki, T., Yoshida, Y., Inoue, A. \& Horikoshi, K. (2005). Organic solvent tolerance of halophilic archaea, Haloarcula strains: effects of $\mathrm{NaCl}$ concentration on the tolerance and polar lipid composition. J Biosci Bioeng 99, 169-174.

Ventosa, A. (2001). Genus V. Haloferax. In Bergey's Manual of Systematic Bacteriology, 2nd edn, vol. 1, pp. 315-318. Edited by D. R. Boone, R. W. Castenholz \& G. M. Garrity. New York: Springer.

Xu, X.-W., Wu, Y.-H., Wang, C.-S., Oren, A., Zhou, P.-J. \& Wu, M. (2007). Haloferax larsenii sp. nov., an extremely halophilic archaeon from a solar saltern. Int J Syst Evol Microbiol 57, 717-720. 